\title{
Phytoremediation of Heavy Metals from Industrial Effluent Using Constructed Wetland Technology
}

\author{
Dipu Sukumaran* \\ Central Pollution Control Board Zonal Office- Kolkata, Southend Conclave India, India \\ *Corresponding author: dipudr@rediffmail.com
}

Received August 08, 2013; Revised October 15, 2013; Accepted October 15, 2013

\begin{abstract}
Phytoremediation is the natural ability of certain plants to bioaccumulate, degrade, or render harmless contaminants in soils, water, or air. In the present study, an attempt to have a comparative assessment of the efficiency of aquatic weeds like Typha latifolia, Eichhornia crassipes, Salvinia molesta and Pistia stratiotes to treat the effluents under laboratory conditions. The bio concentration factor (BCF) of lead, copper, arsenic and cadmium by the floating and emergent plant were studied. The effluent of rare earth separating industry had high concentration of copper, cadmium and arsenic. Eichhornia crassipes and Typha latifolia based constructed wetlands are the best options for treatment of the effluent. Lead from Titanium sponge industry effluent was removed prominently by Eichhornia crassipes than the emergent plant Typha latifolia. But other heavy metals like copper and cadmium was removed prominently by Typha latifolia.
\end{abstract}

Keywords: bioconcentration factor, constructed wetlands, heavy metals, macrophytes, Phytoremediation

Cite This Article: Dipu Sukumaran, "Phytoremediation of Heavy Metals from Industrial Effluent Using Constructed Wetland Technology.” Applied Ecology and Environmental Sciences 1, no. 5 (2013): 92-97. doi: 10.12691/aees-1-5-4.

\section{Introduction}

The environmental pollution with toxic metals has become a worldwide crisis, affecting agriculture and contributing to bioaccumulation and biomagnifications in the food chain. Recently, research groups have recognized that certain toxic metals may remain in the environment for a long period and can eventually bioaccumulate to higher levels that could affect human being [1]. As an alternative, to the traditional treatment of pollutants, an ecological approach has been developed using of plants to remediate soils or water contaminated with toxic metals. Traditional technologies for removal of pollutants can be successful in specific situations, but they are not cost effective. There is very dynamic effort to develop new, more cost-effective and ecofriendly techniques to remediate polluted soils, and now Phytoremediation which is based on the use of plants to extract, sequester or detoxify pollutants is in the front line [2].

Constructed Wetland (CW) is an artificial wetland created as a new habitat for native and migratory wildlife, for anthropogenic discharge such as wastewater or sewage treatment and or other ecological disturbances such as required mitigation for natural areas lost to a development. It acts as a biofilter, removing sediments and pollutants such as heavy metals from the water, and constructed wetlands can be designed to emulate these features. Phytoremediation can be defined as the process of using plants to absorb, accumulate, detoxify and for render harmless, contaminants in the environment through physical, chemical or biological processes [3]. Hartman [4] reported that plants were first proposed for use in the treatment of wastewater above 300 years ago. The sequestration of heavy metal ions by non-living biomass primarily involves adsorption, while absorption followed by accumulation is mechanism associated with living biomass. Early saturation of metal-binding interactive sites of plant biomass limits the capacity for heavy metal uptake [5].

Hyper accumulator plant species accumulate harmful metals above certain concentrations in their shoot, leaf and fruits [6]. The phytoremediation of metals from contaminated soi1 was reintroduced and developed by Chaney [7] and the first field trial of phytoextraction was done in 1991 on zinc and cadmium [8]. Boyd and Martens [9] reported that the accumulation of metals could be a symbol of a defense mechanism against the pests.

Arsenic is a naturally occurring metalloid, which has been used in pesticides and wood preservatives, leading to arsenic contaminated sites [10] and localized soil contaminations resulting from use of arsenic in pressuretreated lumber have been widely reported. The arsenic contamination of ground water in the alluvial planes of Bangladesh and West Bengal, from microbial degradation of peat has resulted in widespread health risk and irrigation practices has dispersed arsenic to surrounding soils, resulting in arsenic poisoning of living beings [11]. Similar contamination is seen in regions with arsenic in sub soils worldwide. Pteris vittata accumulates arsenic in contaminated and non-contaminated soils suggesting that hyper accumulation is a constitutive trait [12]. Various studies propose the use of $P$. vittata for phytoremediation of soil and water. Salido et al. [13] reported that $P$. vittata could remediate contaminated soil sites in within ten years 
and Blaylock et al. [14] reported that $P$. vittata can reduce arsenic levels in water to less than $10 \mu \mathrm{g} \mathrm{L}^{-1}$.

Cadmium is a toxic metal and probable carcinogen associated with zinc mining and industrial operations where cadmium has been used to prevent corrosion of machinery. Resulting air-borne cadmium dust presents a significant health hazard. Hyper accumulation of cadmium in Arabidopsis halleri [15,16] and Brassica juncea [17] has also been reported.

Copper is an essential element and enzyme co-factor for oxidases (cytochrome oxidase, superoxide dismutase) and tyrosinases; however, animals and plants can accumulate toxic levels of copper. At super optimal levels, copper is highly toxic to plants and copper ligands in plants are citrate and metallothioneins [18,19]. Correspondingly, most copper tolerant plants are excluders, and no confirmed copper accumulators have been identified. Salix nigra was shown to accumulate more cadmium and copper than other Salix species, and field studies should determine the feasibility of this species for phytoremediation [20]. Soil amendments like phosphate, increase copper uptake, and speed up phytoremediation [21]. Eichhornia crassipes is estimated to accumulate high levels of copper and could potentially be used remediation of low level copper contamination in waste water [22].

Lead is an extremely toxic heavy metal, which is a serious threat to the health of children and wildlife [23]. Several plant species can hyperaccumulate soluble lead in the soil. It has been reported that Sesbania drummondii, a leguminous shrub, and several Brassica species can accumulate significant amounts of lead in their roots [14,24,25] and Piptatherum miliaceum, a grass, accumulates lead directly correlating to soil concentrations without symptoms of toxicity for 3 weeks [26]. Sahi et al. [24] have noted that $S$. drummondii can tolerate lead levels up to $1500 \mathrm{mg} \mathrm{L}^{-1}$ and accumulate $40 \mathrm{~g} \mathrm{~kg}^{-1}$ shoot dry weight. Lead is accumulated mostly in the stems and not leaves indicating that lead is relatively insoluble [27]. The biggest challenge to effective phytoremediation of lead is its extremely low solubility, as only minute amount of soil lead is available for extraction [28].

Phytoremediation has been projected as a cost-effective unconventional technology for the remediation of arsenic in the soil [29]. Phytoremediation conserve the topsoil and minimize the amount of harmful products generated during cleanup [30]. The rate of biomass production and ability to concentrate elements in the aboveground biomass is the primary criteria for hyper accumulators in Phytoremediation [31].

\section{Methodology}

\subsection{Experimental Set Up for Heavy Metal Uptake by Constructed Wetland}

The constructed wetlands were created by using plastic tubs with $100 \times 45 \times 45$ (cm) dimensions. The bottom of the tub was filled with gravel $(3 \mathrm{~cm})$ above which wetland soil $(5 \mathrm{~cm})$ is filled up.

The experimental plants (Typha latifolia, Eichhornia crassipes, Salvinia molesta and Pistia stratiotes) were collected from the wetlands near the laboratory. The plants were cleaned using distilled water and kept for ten minutes in potassium permanganate solution (1\%). The plants were initially subject to acclimatization in tanks containing fresh water for one month and the second generations of the plants were used for the effluent treatment. Approximately 250g (Fresh Weight) of the second generations of the plants were collected, cleaned, blotted and planted in the constructed wetlands. The entire constructed wetlands (CWs) containing macrophytes were placed in the natural environment.

The Effluents of Travancore Titanium Products (TTP), Kerala, India which is producing titanium sponge is used for treatment. Ten liters of the effluent was added to each constructed wetlands (CWs) for treatment. Triplicate of each experimental setup and a control using fresh water was also maintained.

The initial concentration of heavy metals/metalloid in the plants and effluents were analyzed before introduction into the constructed wetlands. After 15 days of treatment, final concentration of heavy metals/metalloid in effluent samples and plants were analyzed using Atomic Absorption Spectroscopy (SavantAA - AAS; GBC, Germany). The efficiency of each plant in accumulating heavy metals in their leaf and root were calculated using bioconcentration factor.

\subsection{Estimation of Heavy Metals in Effluents}

The heavy metals/metalloid in the effluent viz. lead, cadmium, copper and arsenic were analysed before and after treatment by AAS after digestion of plant materials by diacid method $[32,33]$. The plant samples were washed in deionized water dried ( $24 \mathrm{hrs}$ at $80^{\circ} \mathrm{C}$ ) immediately to stabilize the tissue and stop enzymatic reactions. After drying, samples were ground to pass a $1.0 \mathrm{~mm}$ screen using the appropriate Wiley Mill. After grinding, the sample were thoroughly mixed and a 5- to 8-g aliquot withdrawn for analyses and storage (33). Weighed 0.5 to $1.0 \mathrm{~g}$ of dried $\left(80^{\circ} \mathrm{C}\right)$ plant material that has been ground ( 0.5 to $1.0 \mathrm{~mm})$ and thoroughly homogenized and place in a tall-form beaker or digestion tube. Added $5.0 \mathrm{ml}$ concentrated $\mathrm{HNO}_{3}(70.4 \%)$ and cover beaker with watch glass or place a funnel in the mouth of digestion tube and allow to stand overnight or until frothing subsides. Place covered beaker on hot plate or digestion tube into block digester and heat at $125^{\circ} \mathrm{C}$ for 1 hour. Removed the digestion tube and allowed cooling. Added 1 to $2 \mathrm{ml} 30 \%$ $\mathrm{H}_{2} \mathrm{O}_{2}$ and digest at the same temperature. Repeated heating and $30 \% \mathrm{H}_{2} \mathrm{O}_{2}$ additions until digest is clear. Add additional $\mathrm{HNO}_{3}$ as needed to maintain a wet digest. After sample digest is clear, removed watch glass and lowered temperature to $80^{\circ} \mathrm{C}$. Continued heating until near dryness. Added dilute $\mathrm{HNO}_{3}$ (30\%), and deionized water to dissolve digest residue and bring sample to final volume.

\subsection{Bioconcentration Factor}

The bioconcentration factor is a measure of bioaccumulation of heavy metals. It can be calculated by dividing the trace element concentration in plant tissues (ppm) at harvest by initial concentration of the element in the external nutrient solution (ppm) [34,35].

Concentration of the element

$$
\begin{aligned}
\mathrm{BCF}= & \frac{\text { in plant tissues at harvest }(\mathrm{ppm})}{\text { Initial concentration of the element }} \\
& \text { in the external nutrient solution (ppm) }
\end{aligned}
$$




\subsection{Statistical Analysis}

For testing statistical significance, student's t-test (SPSS14) was used. Independent sample t-test was used for finding the mean difference of each parameter control with plants.

\section{Results and Discussion}

Results of uptake of heavy metals/metalloid viz. lead, copper cadmium and arsenic by wetland plants are described in this section. Bioconcentration factor of the aquatic plants were also quantified. The concentrations of different heavy metals/metalloid in the effluent were given in the Table 1.

Table 1. Concentration of Heavy metals in the effluent

\begin{tabular}{|c|c|}
\hline Heavy Metal & Concentration (ppm) \\
\hline Lead & $2.984 \pm 0.021$ \\
\hline Arsenic & $0.016 \pm 0.004$ \\
\hline Copper & $0.096 \pm 0.012$ \\
\hline Cadmium & $0.253 \pm 0.019$ \\
\hline
\end{tabular}

\subsection{Uptake of Lead from TTP Effluent}

Initial concentration of lead in TTP effluent was 2.98 ppm. On treatment with different plant based CWs, there was no significant decrease in lead concentration of the effluent. However Eichhornia sp. based CWs made the reduction of lead at a higher level ( $p<0.05)$. The least efficient was Pistia sp. based CWs.

After 15 days of treatment, concentration of lead in Typha sp. leaf increased from $0.006 \mathrm{mg} / \mathrm{g}$ to $0.521 \mathrm{mg} / \mathrm{g}$. The bioconcentration factor was 174.60. In case of Typha sp. root, the initial concentration was $0.021 \mathrm{mg} / \mathrm{g}$, which then increased to $0.624 \mathrm{mg} / \mathrm{g}$. The initial concentration of lead in Salvinia sp. leaf was $0.013 \mathrm{mg} / \mathrm{g}$ and after treatment, the concentration increased to $0.186 \mathrm{mg} / \mathrm{g}$. In case of Salvinia sp. root, the initial concentration was $0.027 \mathrm{mg} / \mathrm{g}$, which then increased to $0.290 \mathrm{mg} / \mathrm{g}$.

The initial concentration of lead in Eichhornia sp. leaf was $0.006 \mathrm{mg} / \mathrm{g}$ and after treatment, the concentration increased to $0.191 \mathrm{mg} / \mathrm{g}$. The bioconcentration factor was 64.01. In case of Eichhornia sp. root, the initial concentration was $0.008 \mathrm{mg} / \mathrm{g}$, which then increased to $0.211 \mathrm{mg} / \mathrm{g}$. The bioconcentration factor was 70.71. In Pistia sp. leaf, the concentration of lead before treatment was $0.046 \mathrm{mg} / \mathrm{g}$. After treatment, the concentration increased to $0.197 \mathrm{mg} / \mathrm{g}$. The bioconcentration factor was 66.02. In case of Pistia sp. root, the initial concentration was $0.012 \mathrm{mg} / \mathrm{g}$ which then increased to $0.276 \mathrm{mg} / \mathrm{g}$ (Table 2).

Table 2. Uptake of lead from TTP effluent

\begin{tabular}{|c|c|c|c|c|c|c|}
\hline \multirow{2}{*}{ Plants } & \multirow{2}{*}{} & \multicolumn{2}{|c|}{$\begin{array}{c}\text { Conc. of lead in TTP effluent* } \\
(\mathrm{ppm})\end{array}$} & \multicolumn{2}{c|}{$\begin{array}{c}\text { Conc. of lead in plants* } \\
\text { (mg/g) }\end{array}$} \\
\cline { 3 - 7 } & & Initial & Final & Initial & Final & \\
\hline \multirow{2}{*}{ Typha sp. } & Leaf & $2.984 \pm 0.021$ & $1.324 \pm 0.12 \cdot$ & $0.006 \pm 0.002$ & $0.521 \pm 0.023$ & 174.60 \\
\cline { 2 - 7 } & root & $2.984 \pm 0.021$ & $1.324 \pm 0.14 \bullet$ & $0.021 \pm 0.006$ & $0.624 \pm 0.031$ & 209.12 \\
\hline \multirow{2}{*}{ Pistia sp. } & Leaf & $2.984 \pm 0.021$ & $2.043 \pm 0.18$ & $0.046 \pm 0.004$ & $0.197 \pm 0.012$ & 66.02 \\
\cline { 2 - 7 } & root & $2.984 \pm 0.021$ & $2.043 \pm 0.13$ & $0.012 \pm 0.002$ & $0.276 \pm 0.014$ & 92.49 \\
\hline \multirow{2}{*}{ Salvinia sp. } & Leaf & $2.984 \pm 0.021$ & $1.964 \pm 0.19$ & $0.013 \pm 0.001$ & $0.186 \pm 0.011$ & 62.33 \\
\cline { 2 - 7 } & root & $2.984 \pm 0.021$ & $1.964 \pm 0.09$ & $0.027 \pm 0.004$ & $0.290 \pm 0.021$ & 97.18 \\
\hline \multirow{2}{*}{ Eichhornia sp. } & Leaf & $2.984 \pm 0.021$ & $1.012 \pm 0.14$ & $0.006 \pm 0.001$ & $0.191 \pm 0.018$ & 64.01 \\
\cline { 2 - 7 } & root & $2.984 \pm 0.021$ & $1.012 \pm 0.11$ & $0.008 \pm 0.002$ & $0.211 \pm 0.016$ & 70.71 \\
\hline
\end{tabular}

* Values are mean of triplicates

- Statistically significant at $0.05 \%$ level

\subsection{Uptake of Arsenic from TTP Effluent}

The initial amount of arsenic in TTP effluent was 0.016 ppm. After treatment with different plant based CWs, the concentration reduced considerably. Salvinia sp. was the least efficient macrophyte used for the removal of arsenic from TTP effluent. The initial concentration of arsenic in Salvinia sp. leaf was $0.005 \mathrm{mg} / \mathrm{g}$ and after treatment with TTP effluent the concentration increased to $0.010 \mathrm{mg} / \mathrm{g}$. In case of Salvinia sp. root, the initial concentration was $0.001 \mathrm{mg} / \mathrm{g}$, which then increased to $0.008 \mathrm{mg} / \mathrm{g}$.

After 15 days of treatment, concentration of arsenic in Typha sp. leaf increased from $0.002 \mathrm{mg} / \mathrm{g}$ to $0.021 \mathrm{mg} / \mathrm{g}$. In case of Typha sp. root, the initial concentration was $0.003 \mathrm{mg} / \mathrm{g}$, which then increased to $0.024 \mathrm{mg} / \mathrm{g}$. In Pistia sp. leaf, the concentration of arsenic increased to 0.014 $\mathrm{mg} / \mathrm{g}$ from $0.006 \mathrm{mg} / \mathrm{g}$. In case of Pistia sp. root, the initial concentration was $0.001 \mathrm{mg} / \mathrm{g}$, which then increased to $0.018 \mathrm{mg} / \mathrm{g}$ with bioconcentration factor of 1125 .

Table 3. Uptake of arsenic from TTP effluent

\begin{tabular}{|c|c|c|c|c|c|c|}
\hline \multirow{2}{*}{ Plants } & \multirow{2}{*}{} & \multicolumn{2}{|c|}{$\begin{array}{c}\text { Conc. of arsenic in TTP effluent* } \\
\text { (pm) }\end{array}$} & \multicolumn{2}{c|}{$\begin{array}{c}\text { Conc. of arsenic in plants* } \\
\text { (mg/g) }\end{array}$} \\
\cline { 3 - 7 } & & Initial & Final & Initial & Final & \\
\hline \multirow{2}{*}{ Typha sp. } & Leaf & $0.016 \pm 0.004$ & $0.002 \pm 0.0003$ & $0.002 \pm 0.001$ & $0.021 \pm 0.007$ & 1312.5 \\
\cline { 2 - 7 } & root & $0.016 \pm 0.004$ & $0.002 \pm 0.0002$ & $0.003 \pm 0.001$ & $0.024 \pm 0.012$ & 1500 \\
\hline \multirow{2}{*}{ Pistia sp. } & Leaf & $0.016 \pm 0.004$ & $0.004 \pm 0.0002$ & $0.006 \pm 0.002$ & $0.014 \pm 0.021$ & 875 \\
\cline { 2 - 7 } & root & $0.016 \pm 0.004$ & $0.004 \pm 0.0003$ & $0.001 \pm 0.001$ & $0.018 \pm 0.020$ & 1125 \\
\hline \multirow{2}{*}{ Salvinia sp. } & Leaf & $0.016 \pm 0.004$ & $0.011 \pm 0.0004$ & $0.005 \pm 0.002$ & $0.010 \pm 0.019$ & 625 \\
\cline { 2 - 7 } & root & $0.016 \pm 0.004$ & $0.011 \pm 0.0003$ & $0.001 \pm 0.002$ & $0.008 \pm 0.018$ & 500 \\
\hline \multirow{2}{*}{ Eichhornia sp. } & Leaf & $0.016 \pm 0.004$ & $0.005 \pm 0.0005$ & $0.001 \pm 0.001$ & $0.012 \pm 0.013$ & 750 \\
\cline { 2 - 7 } & root & $0.016 \pm 0.004$ & $0.005 \pm 0.0006$ & $0.004 \pm 0.002$ & $0.017 \pm 0.017$ & 1062.5 \\
\hline
\end{tabular}

* Values are mean of triplicates

- Statistically significant at $0.05 \%$ level 
The initial concentration of arsenic in Eichhornia sp. leaf was $0.001 \mathrm{mg} / \mathrm{g}$ and after treatment with TTP effluent the concentration increased to $0.012 \mathrm{mg} / \mathrm{g}$. The bioconcentration factor was 750. In case of Eichhornia sp. root, the initial concentration was $0.004 \mathrm{mg} / \mathrm{g}$, which then increased to $0.017 \mathrm{mg} / \mathrm{g}$ and the bioconcentration factor was 1062.5 (Table 3).

\subsection{Uptake of Copper from TTP Effluent}

The amount of copper in TTP effluent was $0.096 \mathrm{ppm}$. Salvinia sp. concentrated significant amount of copper from TTP effluent $(\mathrm{p}<0.05)$ of which the most efficient was Typha sp. based CWs.

After 15 days of treatment, concentration of copper in Typha sp. leaf increased from $0.005 \mathrm{mg} / \mathrm{g}$ to $0.086 \mathrm{mg} / \mathrm{g}$. The bioconcentration factor was 895.83. In case of Typha sp. root, the initial concentration was $0.031 \mathrm{mg} / \mathrm{g}$, which then increased to $0.101 \mathrm{mg} / \mathrm{g}$. The bioconcentration factor was 1052.08 .

The initial concentration of copper in Salvinia sp. leaf was $0.068 \mathrm{mg} / \mathrm{g}$ and after treatment with TTP effluent the concentration increased to $0.083 \mathrm{mg} / \mathrm{g}$. In case of Salvinia sp. root, the final concentration of copper was increased to $0.072 \mathrm{mg} / \mathrm{g}$ from $0.123 \mathrm{mg} / \mathrm{g}$ and the bioconcentration factor was 750. The initial concentration of copper in Eichhornia sp. leaf was $0.005 \mathrm{mg} / \mathrm{g}$ and after treatment, increased to $0.069 \mathrm{mg} / \mathrm{g}$. In case of Eichhornia sp. root, the initial concentration was $0.014 \mathrm{mg} / \mathrm{g}$, which then increased to $0.046 \mathrm{mg} / \mathrm{g}$ and the bioconcentration factor was 479.17. In Pistia sp. leaf, the concentration of copper before treatment was $0.002 \mathrm{mg} / \mathrm{g}$. After treatment with TTP effluent, the concentration increased to $0.064 \mathrm{mg} / \mathrm{g}$. In case of Pistia sp. root, the initial concentration of copper was $0.057 \mathrm{mg} / \mathrm{g}$, which then increased to 0.071 $\mathrm{mg} / \mathrm{g}$ and the bioconcentration factor was 739.58 (Table 4).

Table 4. Uptake of copper from TTP effluent

\begin{tabular}{|c|c|c|c|c|c|c|}
\hline \multirow{2}{*}{ Plants } & \multirow{2}{*}{} & \multicolumn{2}{|c|}{ Conc. of copper in TTP effluent* } & \multicolumn{2}{|c|}{$\begin{array}{c}\text { Conc. of copper in plants* } \\
\text { (mp/g) }\end{array}$} & \multirow{2}{*}{ BCF } \\
\cline { 3 - 7 } & & Initial & Final & Initial & Final & \\
\hline \multirow{2}{*}{ Typha sp. } & Leaf & $0.096 \pm 0.012$ & $0.024 \pm 0.002 \bullet$ & $0.005 \pm 0.001$ & $0.086 \pm 0.009$ & 895.83 \\
\cline { 2 - 7 } & root & $0.096 \pm 0.012$ & $0.024 \pm 0.009 \bullet$ & $0.031 \pm 0.008$ & $0.101 \pm 0.011$ & 1052.08 \\
\hline \multirow{2}{*}{ Pistia sp. } & Leaf & $0.096 \pm 0.012$ & $0.028 \pm 0.012$ & $0.002 \pm 0.001$ & $0.064 \pm 0.016$ & 666.67 \\
\cline { 2 - 7 } & root & $0.096 \pm 0.012$ & $0.028 \pm 0.011$ & $0.057 \pm 0.009$ & $0.071 \pm 0.016$ & 739.58 \\
\hline \multirow{2}{*}{ Salvinia sp. } & Leaf & $0.096 \pm 0.012$ & $0.025 \pm 0.003 \bullet$ & $0.068 \pm 0.008$ & $0.083 \pm 0.009$ & 864.58 \\
\cline { 2 - 7 } & root & $0.096 \pm 0.012$ & $0.025 \pm 0.005 \bullet$ & $0.123 \pm 0.023$ & $0.072 \pm 0.014$ & 750.00 \\
\hline \multirow{2}{*}{ Eichhornia sp. } & Leaf & $0.096 \pm 0.012$ & $0.062 \pm 0.004 \bullet$ & $0.005 \pm 0.001$ & $0.069 \pm 0.008$ & 718.75 \\
\cline { 2 - 7 } & root & $0.096 \pm 0.012$ & $0.062 \pm 0.005 \bullet$ & $0.014 \pm 0.005$ & $0.046 \pm 0.007$ & 479.17 \\
\hline
\end{tabular}

* Values are mean of triplicates

- Statistically significant at $0.05 \%$ level

\subsection{Uptake of Cadmium from TTP Effluent}

Cadmium concentration in TTP effluent was 0.253 ppm. CWs using Eichhornia sp., Typha sp. was very effective in removing the cadmium from the effluent, which was statistically significant ( $\mathrm{p}<0.05)$. Among these, Typha sp. based system was more effective. The least efficient was Salvinia sp. based CWs.
After 15 days of treatment, concentration of cadmium in Typha sp. leaf increased from $0.001 \mathrm{mg} / \mathrm{g}$ to $0.027 \mathrm{mg} / \mathrm{g}$ with BCF of 106.72. In case of Typha sp. root, the initial concentration was $0.001 \mathrm{mg} / \mathrm{g}$, which then increased to $0.047 \mathrm{mg} / \mathrm{g}$ (BCF- 185.77). In Pistia sp. leaf, the concentration of cadmium was increased from $0.003 \mathrm{mg} / \mathrm{g}$ to $0.032 \mathrm{mg} / \mathrm{g}$ (BCF- 126.48). In case of Pistia sp. root, the initial concentration was $0.004 \mathrm{mg} / \mathrm{g}$, which then increased to $0.02 \mathrm{mg} / \mathrm{g}$.

Table 5. Uptake of cadmium from TTP effluent

\begin{tabular}{|c|c|c|c|c|c|c|}
\hline \multirow{2}{*}{ Plants } & \multirow{2}{*}{} & \multicolumn{2}{|c|}{$\begin{array}{c}\text { Conc. of cadmium in TTP effluent* } \\
\text { (ppm) }\end{array}$} & \multicolumn{2}{c|}{$\begin{array}{c}\text { Conc. of cadmium in plants* } \\
\text { (mg/g) }\end{array}$} & BCF \\
\cline { 3 - 7 } & & Initial & Final & Initial & Final & \\
\hline \multirow{2}{*}{ Typha sp. } & Leaf & $0.253 \pm 0.019$ & $0.102 \pm 0.015 \bullet$ & $0.001 \pm 0.0002$ & $0.027 \pm 0.005$ & 106.72 \\
\cline { 2 - 7 } & root & $0.253 \pm 0.019$ & $0.102 \pm 0.016 \bullet$ & $0.001 \pm 0.0003$ & $0.047 \pm 0.006$ & 185.77 \\
\hline \multirow{2}{*}{ Pistia sp. } & Leaf & $0.253 \pm 0.019$ & $0.184 \pm 0.009$ & $0.003 \pm 0.001$ & $0.032 \pm 0.004$ & 126.48 \\
\cline { 2 - 7 } & root & $0.253 \pm 0.019$ & $0.184 \pm 0.007$ & $0.004 \pm 0.002$ & $0.02 \pm 0.005$ & 79.05 \\
\hline \multirow{2}{*}{ Salvinia sp. } & Leaf & $0.253 \pm 0.019$ & $0.206 \pm 0.012$ & $0.002 \pm 0.001$ & $0.017 \pm 0.004$ & 67.19 \\
\cline { 2 - 7 } & root & $0.253 \pm 0.019$ & $0.206 \pm 0.014$ & $0.003 \pm 0.001$ & $0.021 \pm 0.007$ & 83.00 \\
\hline \multirow{2}{*}{ Eichhornia sp. } & Leaf & $0.253 \pm 0.019$ & $0.132 \pm 0.009 \bullet$ & $0.003 \pm 0.001$ & $0.015 \pm 0.001$ & 59.29 \\
\cline { 2 - 7 } & root & $0.253 \pm 0.019$ & $0.132 \pm 0.008$ & $0.003 \pm 0.001$ & $0.024 \pm 0.002$ & 94.86 \\
\hline
\end{tabular}

* Values are mean of triplicates

- Statistically significant at $0.05 \%$ level

The initial concentration of cadmium in Salvinia sp. leaf was $0.002 \mathrm{mg} / \mathrm{g}$ and after treatment with TTP effluent, the concentration increased to $0.017 \mathrm{mg} / \mathrm{g}$. The bioconcentration factor was 67.19. In the case of Salvinia sp. root, the initial concentration was $0.003 \mathrm{mg} / \mathrm{g}$, which then increased to $0.021 \mathrm{mg} / \mathrm{g}$. The initial concentration of cadmium in Eichhornia sp. leaf was $0.003 \mathrm{mg} / \mathrm{g}$ and after treatment with TTP effluent the concentration increased to $0.015 \mathrm{mg} / \mathrm{g}$. The bioconcentration factor was 59.29. In case of Eichhornia sp. root, the initial concentration was $0.003 \mathrm{mg} / \mathrm{g}$, which then increased to $0.024 \mathrm{mg} / \mathrm{g}$. The bioconcentration factor was 94.86 (Table 5).

\section{Discussion}

Industrial effluents are one of the important sources of soil and water contamination. The industrial wastewater 
usually contains high level of hazardous material, removal of which is not possible with routine treatments. Industrial water in case of entrance into the soil, surface and ground water, cause pollutions and poison food chain. Additionally, limitation of fresh water and increasing population, treatment and recycling of raw sewage makes essential. Bioconcentration factor (BCF) is a useful parameter to evaluate the potential of the plants in accumulating metals. Metal accumulations by macrophytes could be affected by metal concentrations in water and sediments. The ambient metal concentration in water is the major factor influencing the metal uptake efficiency. In general, when the metal concentration in water increases, the amount of metal accumulation in plants also increases.

The heavy metal concentrations in various effluents were comparatively higher. The increased salinity induces protective mechanisms, which influence the ability of the plant to bioaccumulate metals [36]. Rai [37] reported 7094 per cent decrease in cadmium when Azolla pinnata was used for phyto remediation in thirteen days of treatment. Shugeng et al. [38] observed significant decrease in the concentration of cadmium and lead by Canna sp.

TTP effluent was acidic in nature, where the bioconcentration factor of plants was less. The removal of lead was high by Typha sp. (root) and less by Salvinia sp. (leaf). Among floating macrophytes, Salvinia sp. (root) removed more lead. The bioconcentration factor of arsenic was above 1000 in Typha sp. root and leaves. Among floating plants, Eichhornia sp. (root), which had BCF more than 1000 removed arsenic to maximum. In the removal of copper from the effluent, Typha sp. (root) was observed to be a positive candidate which had BCF higher than 1000. Among floating plants, Salvinia sp. (leaf) removed maximum copper from TTP effluent. The removal of cadmium was comparatively low. The maximum removal of cadmium was by Typha sp. (root). In TTP effluent also, the emergent species Typha sp. was the most efficient in removal of heavy metals. The occurrence of both fibrous and tap root system possessed by Typha sp. enable them to absorb heavy metals from both soil and aqueous medium. Among floating macrophytes Eichhornia sp., Salvinia sp. and Pistia sp. could be used efficiently for heavy metal removal.

The appropriateness of a plant for phytoremediation potential is often judged by its BCF. Plants having BCF values over 1000 are generally considered a positive plant for phytoremediation [36]. However, in this study, with the BCF values of plants were slightly below 1000; these plants could be considered as moderate accumulators. Peng et al. [39] reported high level uptake of cadmium (92 per cent), copper (70 per cent) and lead (79 per cent) by Potamogeton sp.

Among floating macrophytes, Salvinia sp. root (arsenic) and Eichhornia sp. root (copper) had highest BCF than other plants used for the experiment. Tiwari et al. [40] reported that Portulaca sp. growing in effluent irrigated soils had high accumulation of metals in all plant parts with the maximum being in roots and the least in flowers. Among the four heavy metals studied, cadmium was effectively removed by all the plants except Pistia stratiotes. Verma et al. [41] reported that lead uptake by water hyacinth (Eichhornia crassipes) was high from pulp and paper industry effluent and could be used along with expensive cleanup technologies in industrial sector. Cheng et al. [42] studied the efficiency of constructed wetlands in decontamination of water polluted by heavy metals and observed low level removing efficiency for cadmium (6 per cent) and lead (14 per cent). Stoltz and Greger, [43] observed that Typha sp. grown in the mine tailings showed shoot cadmium concentrations varying from 0.4 to 12.5 and lead from 3.4 to $38.3 \mathrm{mg} \mathrm{kg}^{-1}$, while the root varied from 0.1 to $6.2 \mathrm{mg} \mathrm{kg}^{-1}$ cadmium, and from 8.1 to $920 \mathrm{mg} \mathrm{kg}^{-1}$ lead. Mishra et al. [44] reported that Lemna minor (71.4\%) and Eichhornia crassipes (63.6\%) of Copper content from paper mill effluent. Gandhimathi et al. [45] studied the biosorption of $\mathrm{Cu}$ (II) and $\mathrm{Zn}$ (II) ions from aqueous solution by raw water hyacinth and acid treated water hyacinth was studied as a function of time, biosorbent dosage and $\mathrm{pH}$.

Johanna and Maria [46] in their studies on constructed wetlands for preventing and treating acid mine drainage reported that emergent plants were inadequate to treat the very harsh acid mine drainage containing copper. Wang et al. [12] reported that Eichhornia sp. and Pistia sp. strongly accumulated cadmium with BCF values of 1225 and 2567, respectively. Anning et al. [47] reported high rate of hyper accumulation of heavy metals by Typha latifolia, Limnocharis flava and Thalia geniculata.

\section{Conclusion}

Lead from TTP effluent was removed maximum by Eichhornia crassipes than the emergent plant. But all the other heavy metals/metalloid viz. copper, cadmium and arsenic was removed prominently by Typha latifolia. So Typha latifolia can be considered as the best plant for the Phytoremediation of TTP effluent.

\section{Acknowledgement}

The author acknowledges with gratitude the help and support from Prof. \& Head Department of Environmental Sciences, University of Kerala. Thanks are also due to University Grants Commission, India for the financial support to complete the project.

\section{References}

[1] Dipu, S., Anju A. K., Salom Gnana Thanga V “ Phytoremediation of dairy effluent by constructed wetland technology”, Environmentalist, 31 (3), 263-268. 2011.

[2] Capuana, M., "Heavy metals and woody plants - biotechnologies for Phytoremediation,” Biogeosciences and Forestry, 4, 7-15. 2011.

[3] Cunningham, S. D., Berti, W.R. "Remediation of contaminated soi1 with green plants: an overview,” In Vitro Cell Dev. Biol. 29, 207-212. 1993.

[4] Hartman, W. J., An evaluation of land treatment of municipal wastewater and physical siting of facility installations, Washington DC, US Department of Army, 432-467. 1975.

[5] Dhir, B., "Use of aquatic plants in removing heavy metals from waste water," International Journal of Environmental Engineering, 2, 185. 2010.

[6] Kabata, P. A., Pendias, H., Trace Elements in Soils and Plants, CRC Press, Boca Raton, FL, 112-126. 2001.

[7] Chaney, R. L., Plant uptake of inorganic waste, In: Land Treatment of Hazardous Waste (Eds: Parr J.E., Marsh P.B., Kla J.M.) Noyes Data Corp, Park Ridge, 50-76. 1983. 
[8] Baker, A. J. M., Reeves, R. D., McGrath, G. P., In situ decontamination of heavy metal polluted soils using crops of metal accumulating plants- a feasibility study, In; insitu Bioreclamation (Ed: Hinchee), Stohneham, 539-544. 1991.

[9] Boyd, R. S., Martens, S. N., "Nickel hyperaccurnulated between Thlaspi and Montanum is acutely toxic to an insect herbivore," Oikos, 70, 21-25. 1994

[10] Meharg, A. A., Hartley-Whitaker, J., "Arsenic uptake and metabolism in arsenic resistant and nonresistant plant species," New Phytologist, 154, 29-43. 2002.

[11] McArthur, J., Ravenscroft, P., Safiulla, S., Thirlwall, M. F., "Arsenic in groundwater: Testing pollution mechanisms for sedimentary aquifers in Bangladesh," Water Resources Research, 37, 109-117. 2001.

[12] Wang, Q., Cui, Y., Dong, Y., "Phytoremediation of Polluted Waters; Potentials and Prospects of Wetland Plants," Engineering in Life Sciences, 22, 199-208. 2002.

[13] Salido, A. L., Hasty, K. L., Lim, J. M., Butcher, D. J., "Phytoremediation of arsenic and lead in contaminated soil using Chinese brake ferns (Pteris vittata) and Indian mustard (Brassica juncea)," International Journal of Phytoremediation, 5, 89-103. 2003.

[14] Blaylock, M., Salt D., Dushenkov, S., Zakharova, O., Gussman, C., Kapulnik, Y., Ensley, B., Raskin, I., "Enhanced accumulation of $\mathrm{Pb}$ in Indian mustard by soil-applied chelating agents," Environmental Science and Technology, 31, 860-865. 1997.

[15] Cosio, C., Keller, C., "Hyper accumulation of cadmium and zinc in Thlaspi caerulescens and Arabidopsis halleri at the leaf cellular level," Plant Physiology, 134, 716-725. 2004.

[16] Kupper, H., Lombi, E., Zhao F. J., McGrath S. P., "Cellular compartmentation of cadmium and zinc in relation to other elements in the hyper accumulator Arabidopsis halleri," Planta, 212, 75-84. 2000.

[17] Salt, D. E., Pickering, I. J., Prince, R.C., Gleba, D., Dushenkov, S., Smith, R. D., Raskin, I. "Metal accumulation by aquacultured seedlings of Indian mustard," Environmental Science and Technology, 31, 1635-1644. 1997.

[18] Murphy, A. S, Eisinger, W. R., Shaff, J. E., Kochian L. V., Taiz, L., "Early copper-induced leakage of $\mathrm{K}^{(+)}$from Arabidopsis halleri seedlings is mediated by ion channels and coupled to citrate efflux,” Plant Physiology, 121, 1375-1382. 1999.

[19] Rauser, W. E., "Structure and function of metal chelators produced by plants: the case for organic acids, amino acids, phytin, and metallothioneins," Cell Biochem. Biophys., 31, 19-48. 1999.

[20] Kuzovkina, Y. A., Knee, M., Quigley, M. F., "Cadmium and copper uptake and translocation in five willow (Salix L.) species," International Journal of Phytoremediation, 6, 269-287. 2004.

[21] Wu, L., Li H., Luo, Y. M., Christie, P. "Nutrients can enhance phytoremediation of copper polluted soil by Indian mustard," Environ Geochem. Health, 26, 331-335. 2004.

[22] Liao, S., Chang, N., "Heavy metal phytoremediation by water hyacinth at constructed wetlands in Taiwan," J. Aquatic Plant Manag., 42, 60-68. 2004.

[23] EPA, Lead in paint, dust, and soil, U.S. Environmental Protection Agency. EPA-HQ-OPPT-2005-0049. 2005

[24] Sahi, S. V., Bryant N. L., Sharma N. C., Singh S. R., "Characterization of a lead hyper accumulator shrub, Sesbania drummondii," Environmental Science and Technology, 36, 46764680. 2002

[25] Wong, J. W. C., Lai, K. M., Su, D. S., Fang, M., “Availability of heavy metals for Brassica chinensis grown in an acidic loamy soil amended with domestic and industrial sewage sludge," Water Air Soil Pollution, 128, 339-353. 2001.

[26] Garcia, G., Faz, A., Cunha, M., "Performance of Piptatherum miliaceum (Smilo grass) in edaphic $\mathrm{Pb}$ and $\mathrm{Zn}$ phytoremediation over a short growth period,” Int. Bio dete. \& Bio deg., 54, 245-250. 2004.

[27] Kumar, P. B., Dushenkov, V., Motto H., Raskin, I., "Phytoextraction: the use of plants to remove heavy metals from soils," Environmental Science and Technology, 29, 1232-1238. 1995.

[28] Huang, J., Chen, J., Berti, W., Cunningham, S., "Phytoremediation of lead-contaminated soils: Role of synthetic chelates in lead phytoextraction. Environmental Science and Technology,” 31, 800-805. 1997.

[29] Lasat, M. M., "Phytoextraction of toxic metals: a review of biological mechanisms,” Journal of Environmental Quality, 31, 109-129. 2002.

[30] Ensley, B. D., Rationale for Use of Phytoremediation, In: Raskin I., Ensley B. D. (Eds.) Phytoremediation of toxic metals using plants to clean up the environment, John Wiley and Sons, 3-12. 2000.

[31] Reeves, R. D., Baker, A. J. M., Metal accumulating plants, In: Raskin I., Ensley B. D. (Eds), Phytoremediation of toxic metals using plants to clean up the environment, John Wiley and Sons, Inc. New York, 193-230. 2000.

[32] APHA, Standard method for examination of water and waste water (15 ${ }^{\text {th }}$ Edition), APHA, AWWA, Washington DC. 1995.

[33] Jones, J. B., Case V. W., Sampling, handling, and analyzing plant tissue samples - Soil testing and plant analysis, SSSA, Inc., Madison, WI, 1990.

[34] Zayed, A., Gowthaman, S., Terry, N., "Phytoaccumulation of trace elements by wetland plants: I. aestivum Linn.," Mutation Research/Genetic Toxicology and Environmental Mutagenesis, 537, 29-41. 1998.

[35] Fu, W, Franco, A., Trapp, S., "Methods for estimating the bioconcentration factor of ionizable organic chemicals", Environ Toxicol Chem., 28, 1372-1379. 2009.

[36] Zurayk, R. A., Khoury, N. F., Tallhouk, S. N., Baalbaki, R. S., "Salinity-heavy metal interactions in four salt tolerant plant species,” Journal of Plant Nutrition, 24, 1773-1786. 2001.

[37] Rai, P. K., "Heavy metal pollution in aquatic ecosystems and its phytoremediation using wetland plants: An eco sustainable approach,” International Journal of Phytoremediation, 10, 133-160. 2008.

[38] Shugeng, L., Kefang, Z., Shaoqi, Z., Liqiu, Z., Qiul,I. C., “ Use of dewatered municipal sludge on Canna growth in pot experiments with a barren clay soil,” Waste Management, 29, 1870-1876. 2009

[39] Peng, K., Luo, C., Lou, L., Li X., Shen, Z., "Bioaccumulation of heavy metals by the aquatic plants Potamogeton pectinatus $\mathrm{L}$. and Potamogeton malaianus Miq. and their potential use for contamination indicators and in wastewater treatment," The Science of the total environment, 392, 22-31. 2008.

[40] Tiwari K. K., Dwivedi S., Mishra S., Srivastava, S., Tripathi, R. D., Singh, N. K., Chakraborty, S., "Phytoremediation efficiency of Portulaca tuberosa rox and Portulaca oleracea L. naturally growing in an industrial effluent irrigated area in Vadodra, Gujarat, India," Environmental Monitoring and Assessment, 147, 123-128. 2008.

[41] Verma, V. K., Gupta, R. K., Rai, J. P. N., "Biosorption of Pb and $\mathrm{Zn}$ from pulp and paper industry effluent by water hyacinth Eichhornia crassipes,” Journal of Scientific \& Industrial Research, 64, 778. 2005.

[42] Cheng, S., Wolfgang, G., Friedhelm, K., Manfred, T., "Efficiency of constructed wetlands in decontamination of water polluted by heavy metals,” Environmental technology, 12, 1039-1043. 2002.

[43] Stoltz, E., Greger, M., "Accumulation properties of $\mathrm{As}, \mathrm{Cd}, \mathrm{Cu}, \mathrm{Pb}$ and $\mathrm{Zn}$ by four wetland plant species growing on submerged mine tailings,” Environ. Exptal. Botany, 47, 271-280. 2002.

[44] Mishra, S., Mohanty, M., Pradhan, C., Patra, H.K., Das, R., Sahoo, S., "Physico-chemical assessment of paper mill effluent and its heavy metal remediation using aquatic macrophytes-a case study at JK Paper mill, Rayagada, India”, Environ Monit Assess.,185, 4347-59. 2013.

[45] Gandhimathi, R., Ramesh, S.T., Arun, V.M., Nidheesh, P.V., "Biosorption of $\mathrm{Cu}(\mathrm{II})$ and $\mathrm{Zn}$ (II) ions from aqueous solution by water hyacinth (Eichhornia crassipes)", Int. J. of Environment and Waste Management, 11, (4), 365-386. 2013.

[46] Johanna, N., Maria, G., "A field study of constructed wetlands for preventing and treating acid mine drainage", Ecological Engineering,” 35. 630-642. 2009.

[47] Anning A.K., Korsah P.E., Addo-Fordjour P., "Phytoremediation of wastewater with Limnocharis flava, Thalia geniculata and Typha latifolia in constructed wetlands", Int Journal of Phytoremediation, 15(5), 452-64. 2013. 